\title{
Palladium-Ceria Catalysts with Enhanced Alkaline Hydrogen Oxidation Activity for Anion Exchange Membrane Fuel Cells
}

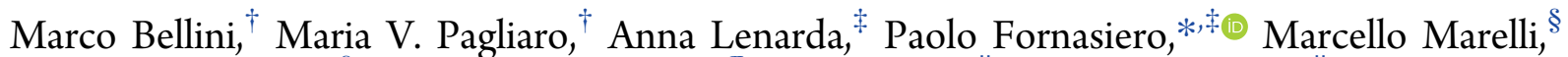

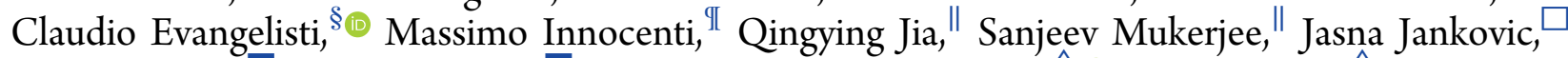

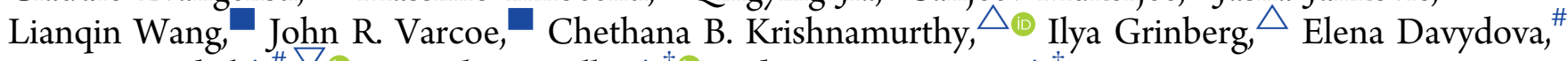
Dario R. Dekel, $, * \#, \nabla \odot$ Hamish A. Miller,,${ }^{\dagger}{ }^{\dagger}$ and Francesco Vizza ${ }^{*}, \dagger$

${ }^{\dagger}$ Istituto di Chimica dei Composti Organometallici (CNR-ICCOM), Via Madonna del Piano 10, 50019, Sesto Fiorentino 50019, Italy

${ }^{\ddagger}$ Department of Chemical and Pharmaceutical Sciences, INSTM, University of Trieste, Via L. Giorgieri 1, Trieste, 34127 Italy

${ }^{\S}$ Istituto di Scienze e Tecnologie Molecolari (ISTM-CNR), via Camillo Golgi 19, 20133 Milano, Italy

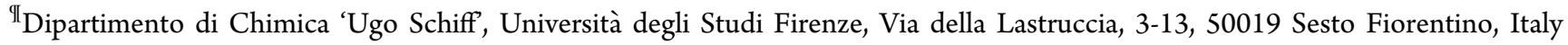

"Department of Chemistry and Chemical Biology, Northeastern University, Boston, Massachusetts 02115, United States

$\square$ Materials Science and Engineering Department, University of Connecticut, Storrs, Connecticut 06269, United States

Department of Chemistry, University of Surrey, Guildford GU2 7XH, U.K.

$\triangle$ Department of Chemistry, Bar-Ilan University, Ramat Gan, 52900, Israel

${ }^{\#}$ The Wolfson Department of Chemical Engineering, Technion-Israel Institute of Technology, Haifa, 3200003, Israel

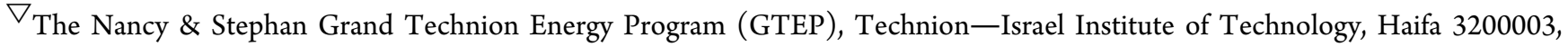
Israel

\section{Supporting Information}

ABSTRACT: Anion exchange membrane fuel cells (AEMFCs) offer several important advantages with respect to proton exchange membrane fuel cells, including the possibility of avoiding the use of platinum catalysts to help overcome the high cost of fuel cell systems. Despite such potential benefits, the slow kinetics of the hydrogen oxidation reaction (HOR) in alkaline media and limitations in performance stability (because of the degradation of the anion conducting polymer electrolyte components) have generally impeded AEMFC development. Replacing $\mathrm{Pt}$ with an active but more sustainable HOR catalyst is a key objective. Herein, we report the synthesis of a $\mathrm{Pd}-\mathrm{CeO}_{2} / \mathrm{C}$ catalyst with engineered $\mathrm{Pd}$-to- $\mathrm{CeO}_{2}$ interfacial contact. The optimized $\mathrm{Pd}-\mathrm{CeO}_{2}$ interfacial contact affords an increased HOR activity leading to $>1.4 \mathrm{~W} \mathrm{~cm}^{-2}$ peak power densities in AEMFC tests. This is the only Pt-free HOR catalyst yet reported that matches state-of-the-art AEMFC power performances $\left(>1 \mathrm{~W} \mathrm{~cm}^{-2}\right)$. Density functional theory calculations suggest that the exceptional HOR activity is attributable to a weakening of the hydrogen binding energy through the interaction of $\mathrm{Pd}$ atoms with the oxygen atoms of $\mathrm{CeO}_{2}$. This interaction is facilitated by a structure that consists of oxidized $\mathrm{Pd}$ atoms coordinated by four $\mathrm{CeO}_{2}$ oxygen atoms, confirmed by X-ray absorption spectroscopy.

KEYWORDS: fuel cells, platinum free, anion exchange membrane, palladium, ceria

\section{INTRODUCTION}

It is well-known that the kinetics of the hydrogen oxidation reaction (HOR) in alkaline media is much slower than in acidic solutions. ${ }^{1,2} \mathrm{~A}$ recent comprehensive review of the current understanding of HOR electrocatalysis in basic media highlights the challenges involved in developing new materials with high activity in this medium. ${ }^{3}$ The large overpotential for the HOR at high $\mathrm{pH}^{3}$ combined with the low efficiency and poor stability of anion exchange membranes (AEMs), ${ }^{4-8}$ are the two main obstacles to the development of high-performance anion exchange membrane fuel cells (AEMFCs). ${ }^{9-11}$
The HOR activity of carbon-supported noble metals (Pt, Pd, and Ir) decreases by around 2 orders of magnitude when transitioning from low to high $\mathrm{pH} .{ }^{12}$ Only recently have researchers approached the problem in a systematic manner with the purpose of elucidating the mechanisms and defining the activity descriptors for the HOR at high $\mathrm{pH}^{2,13-18}$ Most importantly, the role of $\mathrm{OH}^{*}$ in the HOR process under

Received: April 1, 2019

Accepted: June 19, 2019

Published: June 19, 2019 
alkaline conditions is still unclear. ${ }^{3}$ There are two possible mechanisms involving adsorbed hydrogen $\left(\mathrm{H}_{\mathrm{ad}}\right)$ on the metal catalyst surface. ${ }^{3}$ The first is that $\mathrm{H}_{\mathrm{ad}}$ is initially desorbed as a proton (the mechanism that occurs in an acidic environment) which then reacts with $\mathrm{OH}^{-}$to generate water (eqs 1 and 2). If this mechanism predominates at high $\mathrm{pH}$, then the hydrogen binding energy (HBE) would be the sole determining factor for the HOR kinetics.

$$
\begin{aligned}
& \mathrm{H}_{\mathrm{ad}} \rightarrow \mathrm{H}^{+}+\mathrm{e}^{-} \\
& \mathrm{H}^{+}+\mathrm{OH}^{-} \rightarrow \mathrm{H}_{2} \mathrm{O}
\end{aligned}
$$

The second mechanism includes $\mathrm{OH}^{-}$that is also adsorbed on the surface of the metal catalyst $\left(\mathrm{M}-\mathrm{OH}_{\mathrm{ad}}\right)$, where the $\mathrm{H}_{\mathrm{ad}}$ and $\mathrm{OH}_{\mathrm{ad}}$ subsequently react to form water (eqs 3 and 4). With this mechanism, both $\mathrm{HBE}$ and the $\mathrm{OHBE}\left(\mathrm{OH}_{\mathrm{ad}}\right.$ binding energy) would be important for determining the HOR activity.

$$
\begin{aligned}
& \mathrm{OH}^{-} \rightarrow \mathrm{OH}_{\mathrm{ad}}+\mathrm{e}^{-} \\
& \mathrm{H}_{\mathrm{ad}}+\mathrm{OH}_{\mathrm{ad}} \rightarrow \mathrm{H}_{2} \mathrm{O}
\end{aligned}
$$

A series of careful studies of both $\mathrm{Pt}$ and Pt alloy catalysts have led to the general consensus that the main descriptor for HOR activity on noble metals in base is the HBE. ${ }^{12,19,20}$ A pair of important recent studies report the weakening of the $\mathrm{M}-$ $\mathrm{H}_{\mathrm{ad}}$ interaction to be the determining factor in the enhancement of the HOR with surface-controlled Pt-based nanoparticles of well-defined composition: first, with a $\mathrm{PtRu} / \mathrm{C}$ catalyst $^{21}$ and, second, with both alloyed $\mathrm{PtNi}$ nanoparticles and acid-washed PtNi nanoparticles. ${ }^{15}$ The authors concluded that the incorporation of a strongly $\mathrm{OH}$ binding component into the alloy was not beneficial in improving activity. Conversely, the introduction of a foreign atom in $\mathrm{Pt}$ alloys adjusts the electronic state of the $\mathrm{Pt}$ to tune the HBE and increase HOR activity. ${ }^{15}$ Recent work by Lin Zhuang and coworkers confirms the $\mathrm{HBE}$ as the primary descriptor for the alkaline HOR on Pt. Improved activity at higher temperature is linked to a weaker hydrogen bond energy. ${ }^{22}$

The alternative bifunctional mechanism involving adsorbed $\mathrm{OH}$ groups was first investigated by Markovic and coworkers. ${ }^{23}$ They demonstrated that the HOR rate can be improved by optimizing the balance between the active sites required for the adsorption and dissociation of $\mathrm{H}_{2}$ (noble metal, for example, $\mathrm{Pt}$ or $\mathrm{Pd}$ ) and the adsorption of hydroxyl species $\left(\mathrm{OH}_{\mathrm{ad}}\right){ }^{23}$ The conclusion was that a bifunctional catalyst with both $\mathrm{H}$ and $\mathrm{OH}$ adsorption sites is necessary to facilitate the HOR. To show this, the authors prepared a series of bimetallic catalysts with stronger $\mathrm{OH}$ adsorption characteristics and confirmed that this was beneficial for the HOR activity. More recent, experimental proof to support the bifunctional mechanism has been provided for $\mathrm{Pt} / \mathrm{C}$ catalyst with surface doped $\mathrm{Ru}^{13}$ Additional information supporting the bifunctional mechanism has been provided in a recent review. ${ }^{3}$ The presence of $\mathrm{OH}_{\mathrm{ad}}$ species on the surface $\mathrm{Ru}$ sites in the HOR potential region and its promoting effect on the oxidation of $\mathrm{H}_{\mathrm{ad}}$ was demonstrated thereby verifying the bifunctional mechanism for the HOR under alkaline conditions.

We have recently reported Pd NPs deposited on a mixed support of carbon and $\mathrm{CeO}_{2}$, which show improved HOR activity at high $\mathrm{pH}^{24,25}$ When deployed in a Pt-free AEMFC, the $\mathrm{Pd} / \mathrm{C}-\mathrm{CeO}_{2}$ catalyst in combination with a Ag-based cathode, achieved a peak power density of $0.5 \mathrm{~W} \mathrm{~cm}^{-2}$ (at 330 $\mathrm{mV})^{24}$ and more recently, combined with a $\mathrm{PdCu} / \mathrm{C}$ cathode, a record power density of $1 \mathrm{~W} \mathrm{~cm}{ }^{-2}$ (at $\left.420 \mathrm{mV}\right) .{ }^{26}$ Despite fluctuations in the price difference between PGMs, Pd remains a more sustainable alternative to $\mathrm{Pt}$, both in terms of natural abundance and recently reported low toxicity. ${ }^{27}$ Importantly, it is the $\mathrm{Pd}$ to $\mathrm{CeO}_{2}$ interaction that leads to increased HOR activity and has been confirmed for $\mathrm{Pd}-\mathrm{CeO}_{2}$ type materials prepared independently by different synthetic methods. ${ }^{28}$ AEMFCs with high power densities can be realized through the combination of $\mathrm{Pd}-\mathrm{CeO}_{2}$ with PGM-free cathode catalysts for overall system cost reduction.

In this Article, we rationalize the enhancement in the HOR activity of $\mathrm{Pd}-\mathrm{CeO}_{2} / \mathrm{C}$ catalysts and show that the $\mathrm{HOR}$ activity is directly related to the $\mathrm{Pd}-\mathrm{CeO}_{2}$ interfacial structure. The HOR activity is consequently improved by engineering the $\mathrm{Pd}-\mathrm{CeO}_{2}$ interface. A reproducible and scalable synthesis is reported that consists of the addition of $\mathrm{CeO}_{2}$ to carbon using an organometallic precursor followed by $\mathrm{Pd}$ deposition. The resulting $\mathrm{Pd}-\mathrm{CeO}_{2}$ interfacial structure obtained is confirmed by multiple electron microscopies with associated elemental maps produced by energy dispersive $\mathrm{X}$-ray spectroscopy. More than $1.4 \mathrm{~W} \mathrm{~cm} \mathrm{~cm}^{-2}$ peak power density in $\mathrm{H}_{2} / \mathrm{O}_{2}$ AEMFC testing is demonstrated. Furthermore, density functional theory (DFT) calculations confirm that the $\mathrm{H}$ atom adsorbs less strongly on a $\mathrm{Pd}-\mathrm{CeO}_{2}$ surface than that of $\mathrm{Pd}(111)$, suggesting that the $\mathrm{Pd}-\mathrm{CeO}_{2}$ structure deactivates $\mathrm{H}$ adsorption and hence promotes the catalytic HOR.

\section{EXPERIMENTAL SECTION}

All material manipulations during materials preparation, except as stated otherwise, were routinely performed under a $\mathrm{N}_{2}$ atmosphere using standard airless techniques. Carbon black (Vulcan XC-72 pellets) was purchased from Cabot Corp., USA. All metal salts and reagents were purchased from Aldrich and used as received. All the solutions were freshly prepared with doubly distilled deionized water. The benchmark $\mathrm{Pd} / \mathrm{C}$ and $\mathrm{Pd}-\mathrm{CeO}_{2}$ reference catalysts (both $10 \%$ wt. $\mathrm{Pd}$ ) were prepared as described in our previous publications. ${ }^{24,25}$

2.1. Synthesis of $\mathrm{CeO}_{2} / \mathrm{C}$. The $\mathrm{CeO}_{2} / \mathrm{C}$ material was prepared as follows. In a typical synthesis, first $300 \mathrm{mg}$ carbon black was treated for $3 \mathrm{~h}$ in $200 \mathrm{~mL}$ of a $\mathrm{HNO}_{3}$ solution $(4.0 \mathrm{M})$ to functionalize the carbon surface with oxygen bearing groups. This material was then dispersed in ethanol by sonication for $30 \mathrm{~min}$ and a THF solution of cerium(IV) tetrakis(decyloxide) $\left(\mathrm{Ce}\left(\mathrm{C}_{10} \mathrm{H}_{21} \mathrm{O}\right)_{4}\right.$, freshly prepared with a procedure reported elsewhere $)^{29}$ was added dropwise to obtain a final $\mathrm{CeO}_{2}$ loading of $45 \%$ wt. After $30 \mathrm{~min}$ of sonication, $20 \mathrm{~mL}$ of a $10 \%$ vol. solution of $\mathrm{H}_{2} \mathrm{O}$ in ethanol was added dropwise to hydrolyze the alkoxide and form the $\mathrm{C}$-supported amorphous $\mathrm{CeO}_{2}$, which was then further sonicated for $30 \mathrm{~min}$. The solid product was collected by filtration through a $0.45 \mu \mathrm{m}$ PTFE filter and washed thoroughly with ethanol. The solid material thus obtained was dried to constant weight.

2.2. Synthesis of $\mathrm{Pd}-\mathrm{CeO}_{2} / \mathrm{C}$. The $\mathrm{CeO}_{2} / \mathrm{C}$ support material (500 mg) was suspended in $100 \mathrm{~mL}$ of water by vigorous stirring for 1 $\mathrm{h}$ followed by sonication for $30 \mathrm{~min}$. A solution of $\mathrm{K}_{2} \mathrm{PdCl}_{4}(0.17 \mathrm{~g})$ in $20 \mathrm{~mL}$ of water was added $\left(1 \mathrm{~mL} \mathrm{~min}^{-1}\right)$ under stirring, followed by continued stirring for $1 \mathrm{~h}$. To this solution, aqueous $\mathrm{KOH}(2.5 \mathrm{M}, 2.0$ $\mathrm{mL}$ ) was added followed by addition of ethanol $(15 \mathrm{~mL}$, added at 1 $\left.\mathrm{mL} \min ^{-1}\right)$. The mixture was then heated at $80{ }^{\circ} \mathrm{C}$ for $1 \mathrm{~h}$. After cooling to room temperature, the solid product was collected by filtration, washed with water until neutral and then dried to constant weight at $60{ }^{\circ} \mathrm{C}$ in air (Yield $=480 \mathrm{mg}$ ). The \%wt. ratio of the three components in the catalyst $\mathrm{Pd}: \mathrm{CeO}_{2}: \mathrm{C}$ were 1:4:5 respectively (confirmed by TGA, Figure S1).

2.3. Electron Microscopy. Samples for the microscopy characterization were finely ground in an agate mortar, suspended in 
isopropanol, and sonicated, and then, each suspension was dropped onto a holey carbon-coated copper grid (300 mesh) and dried overnight. Transmission electron microscopy (TEM) studies were performed on two instruments: (1) a ZEISS LIBRA200FE microscope equipped with a $200 \mathrm{kV}$ FEG source and energy-dispersive Xray spectra (EDS, Oxford INCA Energy TEM 200) and (2) a FEI TEM Osiris microscope with an accelerating beam voltage of $200 \mathrm{kV}$ and ChemiSTEM EDS detector system, which was utilized for STEM/EDS analysis. Elemental maps were collected along with HAADF-STEM (high angular annular dark field scanning transmission electron microscopy) micrographs.

2.4. Ex Situ X-ray Absorption Spectroscopy (XAS). Measurements were carried out at the $\mathrm{Pd} \mathrm{L}_{3}$-edge in the transmission mode at the beamline 8-ID at the NSLS-II, Brookhaven National Laboratory, USA. The data were processed and fitted using the IFEFFIT-based Athena ${ }^{30}$ and Artemis ${ }^{31}$ programs. Scans were calibrated, aligned and normalized with background removed using the IFEFFIT suite ${ }^{32}$ (version 1.2.9, IFEFFIT Copyright 2005, Matthew Newville, University of Chicago, http://cars9.uchicago.edu/ifeffit/). The $\chi(R)$ were modeled using single scattering paths calculated by FEFF6. ${ }^{33}$

2.5. X-ray Powder Diffraction (XRD). Spectra were acquired at room temperature with a PAN analytical X'PERT PRO diffractometer, employing $\mathrm{CuK} \alpha$ radiation $(\lambda=1.54187 \AA)$ and a parabolic MPD-mirror. The spectra were acquired at room temperature in the $2 \Theta$ range from 5.0 to $120.0^{\circ}$, using a continuous scan mode with an acquisition step size of $0.0263^{\circ}$ and a counting time of $49.5 \mathrm{~s}$. Spectra are shown in the $2 \Theta$ range of $15-90^{\circ}$.

2.6. $\mathrm{H}_{2}$ Temperature-Programmed Desorption $\left(\mathrm{H}_{2}-\mathrm{TPD}\right)$. Analysis of second generation $\mathrm{Pd}-\mathrm{CeO}_{2} / \mathrm{C}$ and $\mathrm{Pd} / \mathrm{C}$ was obtained using an AutoChem 2920 (Micromeritics) operated in the flowing mode. Thermal conductivity detector (TCD) was used to determine the $\mathrm{H}_{2}$ concentration. The samples $(0.1-0.2 \mathrm{~g})$ were placed in the quartz reactor, adsorbed water was removed by heat treating the samples at $200{ }^{\circ} \mathrm{C}$ for $30 \mathrm{~min} . \mathrm{H}_{2}$ adsorption was carried out using at $60{ }^{\circ} \mathrm{C}$ using a mixture of $10 \mathrm{vol} \% \mathrm{H}_{2} / \mathrm{Ar}$ at a flow rate of $50 \mathrm{~mL}$ $\mathrm{min}^{-1}$. Afterward, the gas mixture was switched to Ar with a flow rate of $50 \mathrm{~mL} \mathrm{~min}{ }^{-1}$ until obtaining the baseline of TCD signal. Thermal desorption traces were recorded at the temperature ramp of 10, 20, and $30 \mathrm{deg} \mathrm{min}^{-1}$ up to $500{ }^{\circ} \mathrm{C}$. The resultant curves were deconvoluted using skewed log-normal distribution.

2.7. Cyclic Voltammetry (CV). Measurements were performed with a Princeton 2273A potentiostat/galvanostat, using a threeelectrode arrangement with an $\mathrm{Ag} / \mathrm{AgCl}$ reference electrode and a platinum foil counter electrode $\left(25 \times 25 \times 0.1 \mathrm{~mm}^{3}\right)$. No IR drop compensation was applied to any of the performed experiments. The potential scale of the $\mathrm{CV}$ curves was then converted to the reversible hydrogen electrode (RHE) scale. A portion (1-2 mg) of each catalyst was introduced into a $5 \mathrm{~mL}$ glass vial together with a 50:50 water/ ethanol (99.8\%, Fluka) solution to obtain a $2.5 \mathrm{mg} \mathrm{mL}^{-1}$ dispersion, and 1\%wt. of Nafion 117 solution. The resulting suspension was sonicated for $30 \mathrm{~min}$. The metal loading on each electrode was determined by weighing the amount of the deposited ink onto the glassy carbon electrode.

2.8. Hydrogen Pump Experiments. Tests were carried out using $5 \mathrm{~cm}^{2}$ HOR catalyst coated carbon cloth electrodes as anode combined with an anion exchange membrane (AEM) and a Pt/C cathode electrode for the hydrogen evolution reaction (HER). As HOR catalyst, $\mathrm{Pt} / \mathrm{C}$ (40 wt \%, $0.44 \mathrm{mg}_{\mathrm{Pt}} \mathrm{cm}^{-2}+60$ wt \% AS4 ionomer in catalyst layer) was compared to the various $\mathrm{Pd}$ based materials discussed in this article. Electrodes were prepared by spreading an ink suspension composed of water, 1-propanol, catalyst, and AS4 ionomer solution (Tokuyama corp., Japan) onto carbon cloth supports using a Mayer rod to control the catalyst loading. Prior to use, the AEM (A201, Tokuyama corp., Japan) was hydrated and ion exchanged for $2 \mathrm{~h}$ in $1 \mathrm{M} \mathrm{KOH}$. The membrane electrode assemblies were prepared by mechanically pressing the anode, cathode, and the membrane within the cell testing hardware (Scribner Associates USA). A cell operating temperature of $60{ }^{\circ} \mathrm{C}$ with $100 \%$ relative humidity hydrogen/oxygen gases was used. During cell heating and humidification, $\mathrm{N}_{2}$ was flowed over the HER electrode and $\mathrm{H}_{2}$ through the HOR electrode (both at $100 \mathrm{~mL} \mathrm{~min}^{-1}$ ). Cell stabilization was achieved by slowly ramping from 10 to $100 \mathrm{~mA} \mathrm{~cm}$ $\left(20 \mathrm{~mA} \mathrm{~cm}{ }^{-2}\right.$ increments, 1 min per step), followed by a $30 \mathrm{~min}$ hold at $100 \mathrm{~mA} \mathrm{~cm}{ }^{-2}$. Polarization curves were taken from 50 to $400 \mathrm{~mA}$ $\mathrm{cm}^{-2}$ in $40 \mathrm{~mA} \mathrm{~cm}{ }^{-2}$ increments, followed by a $1 \mathrm{~h}$ constant current test at $300 \mathrm{~mA} \mathrm{~cm}{ }^{-2}$.

2.9. Fuel Cell Testing. MEA Preparation. The catalyst deposited on gas diffusion electrode (GDE) method for preparing AEMFC electrodes was described in previous publications. ${ }^{34-36}$ Prior to preparation of the catalyst ink, a previously benzyltrimethylammonium grafted ETFE-based AEI powder with an IEC $=1.26 \pm 0.06$ mmol g ${ }^{-1}$ was ground with a pestle and mortar for $10 \mathrm{~min}$. The AEI powder used in previous studies and was synthesized via the radiationgrafting of vinylbenzyl chloride onto an ETFE powder (Fluon Z8820X, supplied by AGC Europe) with subsequent amination using trimethylamine. For each cathode GDE, Pt/C (Alfa Aesar, Johnson Matthey HiSpec $4000,40 \mathrm{wt} \% \mathrm{Pt}$ ) and AEI powder (20\% wt. of the total solid mass) were mixed together with $1 \mathrm{~mL}$ water and $9 \mathrm{~mL} \mathrm{2-}$ propanol. The cathode catalyst ink was then homogenized with ultrasound for $30 \mathrm{~min}$, sprayed onto a Toray TGP-H-60 carbon paper gas diffusion substrate (Alfa Aesar, nonteflonated), and dried in air. For the anode GDEs, the $\mathrm{Pd}-\mathrm{CeO}_{2} / \mathrm{C}$ was used as catalyst (with 20 wt $\% \mathrm{AEI})$. The $5 \mathrm{~cm}^{2}$ GDEs were loaded with $0.30 \pm 0.02 \mathrm{mg}_{\text {Pd }} \mathrm{cm}^{-2}$ and $0.40 \pm 0.02 \mathrm{mg}_{\mathrm{Pt}} \mathrm{cm}^{-2}$ for anode and cathode electrodes, respectively.

All electrodes and AEMs (made from radiation-grafting $15 \mu \mathrm{M}$ LDPE with vinylbenzyl chloride, followed by amination with TMA, ion-exchange capacity (IEC) $\left.=2.54 \mathrm{mmol} \mathrm{g}^{-1}\right)^{37}$ were immersed in aqueous $\mathrm{KOH}$ solution $(1 \mathrm{M})$ for $1 \mathrm{~h}$ and then washed thoroughly in water (to remove excess $\mathrm{KOH}$ ) before assembly into a $5 \mathrm{~cm}^{2}$ fuel cell fixture (Scribner Associates, USA) using $5 \mathrm{~N}$ m torque.

2.10. Fuel Cell Performance Data Collection. An 850e fuel cell test station (Scribner Associates, USA) was used for testing. The fuel cell temperature was kept at $80{ }^{\circ} \mathrm{C} . \mathrm{H}_{2}$ and $\mathrm{O}_{2}$ gas feeds with flow rates of 1 and $2 \mathrm{~L} \mathrm{~min}^{-1}$ (SLPM) were supplied to the anode and cathode, respectively, with no back-pressurization. The dew-point for both anode and cathode gas supplies was $76{ }^{\circ} \mathrm{C}$ (calculated relative humidity, $\mathrm{RH}$, of $65 \%$ ). All followers (heated lines between the fuel cell tester and the fuel cell fixture) were set at the same temperatures as the gas dew points. The MEAs were activated by discharging the cell at a constant voltage of $0.5 \mathrm{~V}$ during cell heating, until a steady current density was observed. Beginning-of-life AEMFC performance data were collected under controlled galvanostatic discharge steps where data (at each current density) were recorded after potentials had stabilized. The internal ohmic resistances were estimated using the 850e instrument's internal current interrupt method.

2.11. Density Functional Theory (DFT). Calculations were performed with all electron full potential method implemented in the Fritz-Haber-Institute ab initio molecular simulations (FHI-aims) package. $^{38}$ The atomic zero-order regular approximation (ZORA) was used to treat relativistic effects for all the atoms in the system. ${ }^{39} \mathrm{We}$ used the "tight" settings for integration grids and the exchangecorrelation energy was evaluated with the PBE functional. ${ }^{40}$ The convergence criteria for the energy and force were set to $10-6 \mathrm{eV}$ and $10-4 \mathrm{eV} \AA^{-1}$, respectively. Gaussian smearing with the width of 0.1 $\mathrm{eV}$ was used to speed up the convergence of the states near the Fermi level.

$\mathrm{CeO}_{2}$ (110) surface model was used in this work, consisting of five atomic layers and has a vacuum gap of $10 \AA$ perpendicular to the surface. Monkhorst-Pack Brillouin zone sampling was used with a 13 $\times 13 \times 1$ grid. During the geometry optimization, all the atoms are allowed to relax.

The adsorption energy $E_{\text {ad }}$ is defined as

$$
E_{\text {ads }}=\left(E_{\text {surface+adsorbate }}\right)-\left(E_{\text {surface }}+E_{\text {adsorbate }}\right)
$$

where $E_{\text {surface }}$ and $E_{\text {adsorbate }}$ are the energies of the bare surface and the free adsorbate in the gas phase, respectively, and $E_{\text {surfacetadsorbate }}$ is the total energy of the interacting surface and the adsorbate. According to this equation, a more negative $E_{\text {ad }}$ value corresponds to stronger 
adsorption. The HBE is calculated relative to $\mathrm{H}_{2}$ in the gas phase and is given by

$$
\mathrm{HBE}=E_{\text {surface }+ \text { adsorbate }}-E_{\text {surface }}-0.5 E_{\mathrm{H}_{2}}
$$

where $E_{\mathrm{H}_{2}}$ is the energy of the gas-phase hydrogen molecule. The differential adsorption free energy is given by using the equation reported by Nørskov and co-workers. ${ }^{41}$

\section{RESULTS AND DISCUSSION}

3.1. Catalyst Characterization. An engineered nanostructure that optimizes the active two-phase contact between the $\mathrm{Pd}$ and $\mathrm{CeO}_{2}$ phases has been achieved. An organometallic cerium precursor (cerium(IV) tetrakis(decyloxide) (Ce$\left.\left(\mathrm{C}_{10} \mathrm{H}_{21} \mathrm{O}\right)_{4}\right)$ is used to coat the carbon support particles with a highly homogeneous nanothin layer of nanostructured $\mathrm{CeO}_{2}$ (transition electron microscopy (TEM) and high angular annular dark field scanning transmission electron microscopy (HAADF-STEM) images are shown in Figure 1).
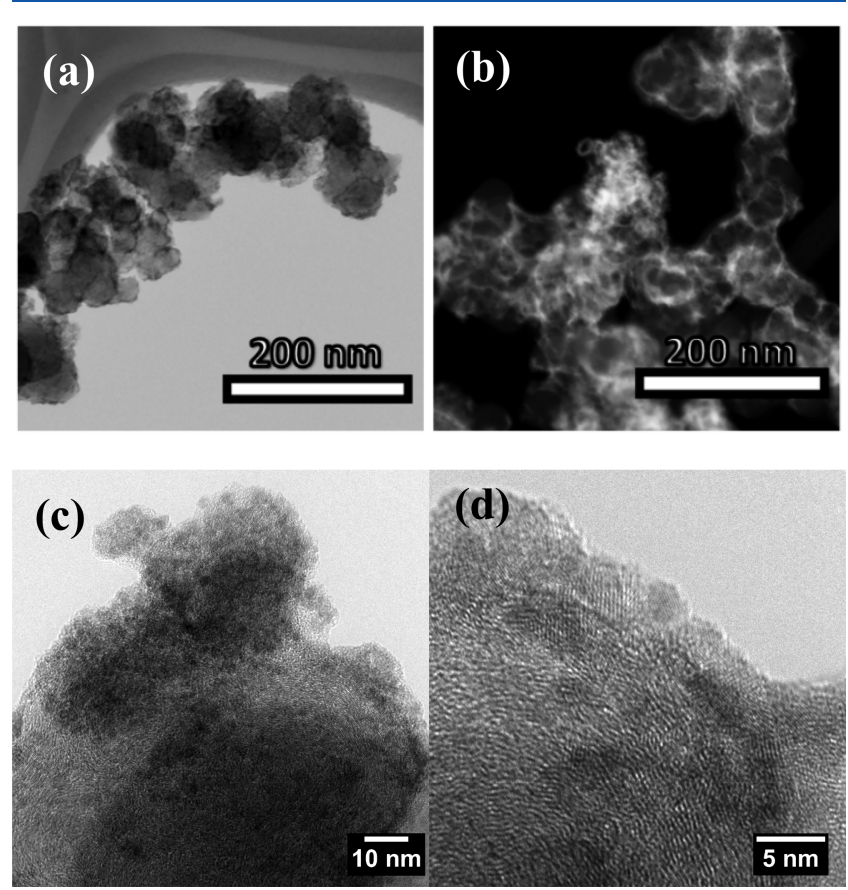

Figure 1. Representative (a) TEM, (b) (HAADF) STEM, (c and d) HR-TEM images of $\mathrm{Pd}-\mathrm{CeO}_{2} / \mathrm{C}$.

High-resolution images show the presence of crystalline nanodomains ranging from 2 to $3 \mathrm{~nm}$ in size. Lattice fringe analysis revealed a $d$-spacing of $3.15 \AA$, characteristic of (111) planes of cubic $\mathrm{CeO}_{2}$. After the addition of $\mathrm{Pd}$, individual nanoparticles are not detected even using high-resolution TEM due to a high dispersion within the $\mathrm{CeO}_{2}$ phase. On the other hand, Pd nanoparticles were not detected even using high resolution TEM or STEM at high magnification due to the possible formation of small $\mathrm{Pd}$ clusters or isolated $\mathrm{Pd}$ atoms embedded in the $\mathrm{CeO}_{2}$ matrix (see X-ray absorption spectroscopy results discussed below). Analysis by HAADFSTEM-EDS (energy-dispersive X-ray spectroscopy) mapping demonstrates the homogeneous distribution of all three components $\left(\mathrm{CeO}_{2}, \mathrm{Pd}\right.$, and $\mathrm{C}$ ) throughout the catalyst (see also Figures $\mathrm{S} 2-\mathrm{S} 4$ ). The images and EDS element maps in Figure 2 show finely dispersed $\mathrm{Pd}$ and $\mathrm{CeO}_{2}$ on the surface of Vulcan carbon support. A semiquantitative analysis resulting
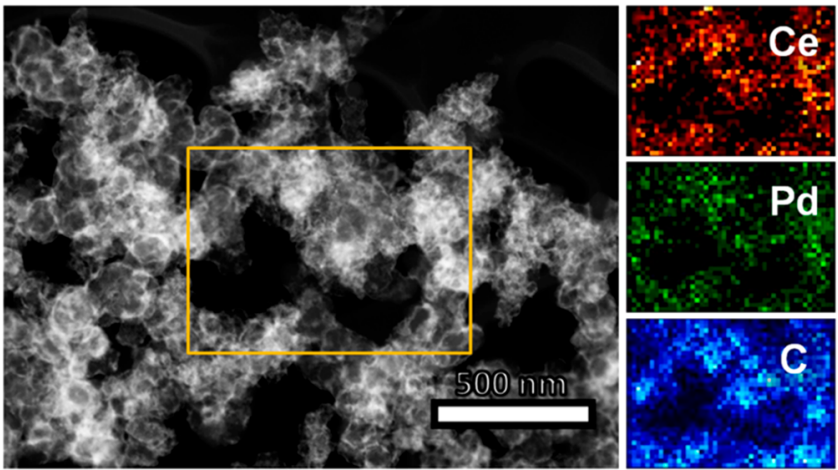

Figure 2. STEM images of $\mathrm{Pd}-\mathrm{CeO}_{2} / \mathrm{C}$ : HAADF image and STEMEDS mapping of the selected area showing the $\mathrm{CeO}_{2}$ (red), $\mathrm{Pd}$ (green), and carbon (blue) elemental maps.

from the EDS spectrum reveals a surface $\mathrm{Pd}$ to $\mathrm{CeO}_{2}$ ratio of $1: 2.3$.

The X-ray powder diffraction (XRD) patterns of $\mathrm{CeO}_{2} / \mathrm{C}$ and $\mathrm{Pd}-\mathrm{CeO}_{2} / \mathrm{C}$ are compared in Figure 3. Both patterns are

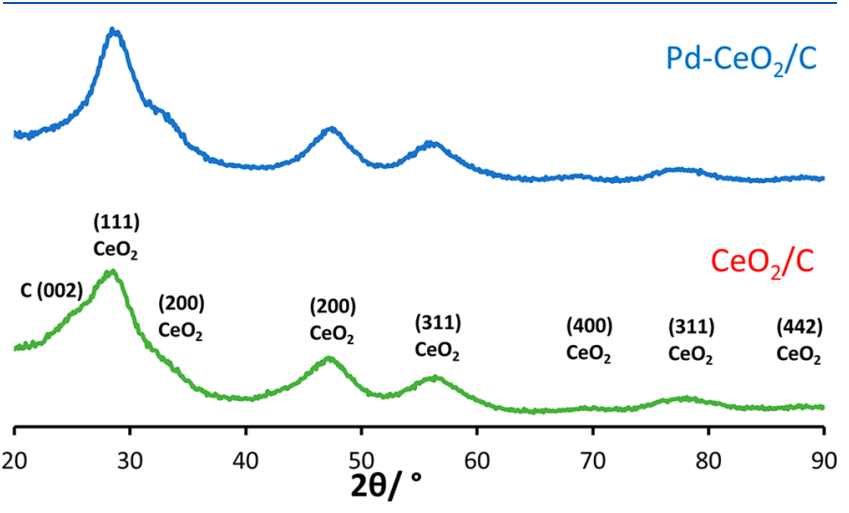

Figure 3. $\mathrm{XRD}$ patterns of $\mathrm{CeO}_{2} / \mathrm{C}$ and $\mathrm{Pd}-\mathrm{CeO}_{2} / \mathrm{C}$.

dominated by the reflections originated by the cubic structure of $\mathrm{CeO}_{2}$; the line broadening of the reflections is consistent with the formation of small nanosized particles of $\mathrm{CeO}_{2}$. The signal representative of metallic $\mathrm{Pd}(0)$ at $2 \theta=40^{\circ} \mathrm{Pd}(111)$ is not visible in the pattern of $\mathrm{Pd}-\mathrm{CeO}_{2} / \mathrm{C}$, indicating noncrystalline, highly oxidized, and small nature of the palladium structures in this catalyst.

The electronic state and local coordination environment of Pd was probed by combining X-ray absorption near edge structure (XANES) and the Fourier transform (FT) of the extended X-ray absorption fine structure (FT-EXAFS) of the spectra collected at the $\mathrm{Pd} \mathrm{L}_{3}$-edge (Figure 4). These spectra are compared together with the XANES and FT-EXAFS of a $\mathrm{Pd}$ reference metallic foil for comparison. The prominent white line intensity of the XANES is comparable to that of a PdO standard (Figure $4 \mathrm{a}$ ) and clearly indicates that the $\mathrm{Pd}$ in $\mathrm{Pd}-$ $\mathrm{CeO}_{2} / \mathrm{C}$ is highly oxidized. This is further confirmed by the prominent $\mathrm{Pd}-\mathrm{O}$ peak around $1.5 \AA$ (without phase correction). The small peak at around $2.5 \AA$ implicates the existence of some metallic Pd, either a very small amount or very small clusters, which is further supported by a reasonable EXAFS fitting excluding the Pd-Pd scattering path (Figure 4b). The EXAFS fitting shows that on average $\mathrm{Pd}$ is surrounded by 3.9 oxygen atoms in the first shell with a typical bond distance of $2.0 \AA$ (Table 1 ). These XAS results together depict a single $\mathrm{Pd}$ atom embedded in $\mathrm{CeO}_{2}$ as the 

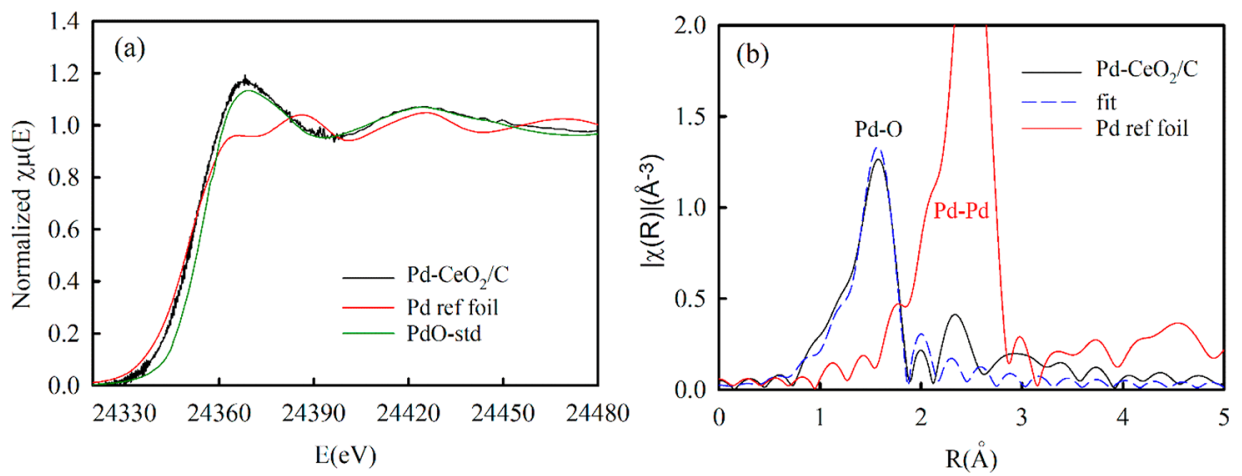

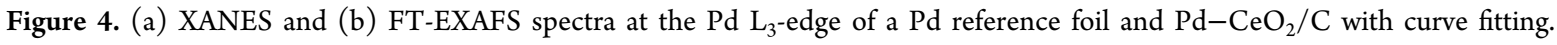

Table 1. Summary of EXAFS Results for $\mathrm{Pd}-\mathrm{CeO}_{2} / \mathrm{C}^{a}$

$\begin{array}{ccccc}\begin{array}{c}\text { scattering } \\ \text { path }\end{array} & \text { edge }(\mathrm{eV}) & \begin{array}{c}\text { bond length } \\ (\AA)\end{array} & \begin{array}{c}\text { coordination } \\ \text { number }\end{array} & \begin{array}{c}\mathrm{D}-\mathrm{W} \text { factor } \\ \left(\AA^{2}\right)\end{array} \\ \mathrm{Pd}-\mathrm{O} & 3.9 \pm 1.8 & 2.00 \pm 0.01 & 3.9 \pm 0.4 & 0.002 \pm 0.001\end{array}$

${ }^{a} S_{0}{ }^{2}$ fixed at 0.62 as obtained by fitting the reference foil. Fits were done in $R$-space, $k^{1,2,3}$ weighting at the $\mathrm{Pt}_{\mathrm{3}}$-edge with the windows of $1.0<R<2.4 \AA$ and $\Delta k=2.93-12.86 \AA^{-1}$. Statistical errors of the least-squares fits were determined by ARTEMIS.

dominant structure in the $\mathrm{Pd}-\mathrm{CeO}_{2} / \mathrm{C}$ catalyst, wherein the $\mathrm{Pd}$ is in contact with the oxygen from $\mathrm{CeO}_{2}$ rather than Ce. The distribution of ceria over the carbon support in $\mathrm{Pd}-$ $\mathrm{CeO}_{2} / \mathrm{C}$ is homogeneous and the $\mathrm{Pd}$ when incorporated interacts solely with $\mathrm{CeO}_{2}$. Such an optimized structure with the direct $\mathrm{Pd}-\mathrm{O}$ interfacial interaction in this new material results in a greatly enhanced HOR activity as favorable electronic interactions are maximized, including the weakening of the $\mathrm{Pd}-\mathrm{H}$ interaction, as demonstrated through $\mathrm{H}_{2}$ temperature-programmed desorption (TPD) analyses and DFT calculations discussed below.

The XAS/XRD studies confirm that the unique structure of $\mathrm{Pd}-\mathrm{CeO}_{2} / \mathrm{C}$ results in an unusually highly oxidized Pd closely coordinated to the oxygen atoms of $\mathrm{CeO}_{2}$. The way that this structure enhances the HOR activity can be elucidated by investigating $\mathrm{H}_{2}$ adsorption/desorption characteristics. Pd$\mathrm{CeO}_{2} / \mathrm{C}$ was studied using TPD analysis and the results compared with those obtained with a $\mathrm{Pd} / \mathrm{C}$ catalyst with the same metal loading. $\mathrm{H}_{2}$-TPD spectra (Figure 5) show distinguishable low temperature $\left(<200{ }^{\circ} \mathrm{C}\right)$ and high temperature $\left(>200{ }^{\circ} \mathrm{C}\right)$ hydrogen desorption peaks which were deconvoluted for both the $\mathrm{Pd} / \mathrm{C}$ and $\mathrm{Pd}-\mathrm{CeO}_{2} / \mathrm{C}$ catalysts.

The mass specific amount of $\mathrm{H}_{2}$ desorbed from $\mathrm{Pd}-\mathrm{CeO}_{2} /$ $\mathrm{C}\left(0.57 \mathrm{mmol} \mathrm{g}_{\text {cat }}{ }^{-1}\right)$ is higher than that measured for $\mathrm{Pd} / \mathrm{C}$ $\left(0.42 \mathrm{mmol} \mathrm{g}_{\text {cat }}{ }^{-1}\right)$. The ratio of the hydrogen desorbed at temperatures below $200{ }^{\circ} \mathrm{C}$ is also much higher for $\mathrm{Pd}-\mathrm{CeO}_{2} /$ C (9.9\%) than for Pd/C (1.6\%). The desorption peaks I and II appear on $\mathrm{Pd}-\mathrm{CeO}_{2} / \mathrm{C}$ spectra at higher temperature values than for $\mathrm{Pd} / \mathrm{C}$. The opposite thermal shift is observed for the peaks III, IV and V: the maximum desorption rate temperature values are higher for $\mathrm{Pd} / \mathrm{C}$. The peak of highest intensity on $\mathrm{Pd} / \mathrm{C}$ is observed at $292{ }^{\circ} \mathrm{C}$ (peak III), while $\mathrm{Pd}-\mathrm{CeO}_{2} / \mathrm{C}$ is mainly populated by the hydrogen desorbing at $312{ }^{\circ} \mathrm{C}$ (peak IV). Full analysis of the experimental data at three different temperature ramp values are presented in the Figures S5-S10.

Below a critical temperature of $298{ }^{\circ} \mathrm{C}$ in $\mathrm{Pd}-\mathrm{H}$ binary systems, two phases can coexist: a solid solution of $\mathrm{H}$ in $\mathrm{Pd}(\alpha$ phase) and the Pd hydride ( $\beta$-phase) ${ }^{42}$ It is known that, at room temperature, $\mathrm{Pd}$ can absorb $\mathrm{H}_{2}$ to form $\mathrm{Pd}$ hydride at a $\mathrm{H}_{2}$ partial pressure exceeding 0.013 atm (at lower partial pressures $\mathrm{H}_{2}$ dissolves only sparingly to form the $\alpha$-phase). Over the temperature range of $50-100{ }^{\circ} \mathrm{C}$, decomposition of $\mathrm{Pd}$ hydride species from supported $\mathrm{Pd}$ catalysts has been previously reported. ${ }^{43}$ Thus, on the basis of the literature data, ${ }^{44}$ the desorption peaks I and II at temperatures below

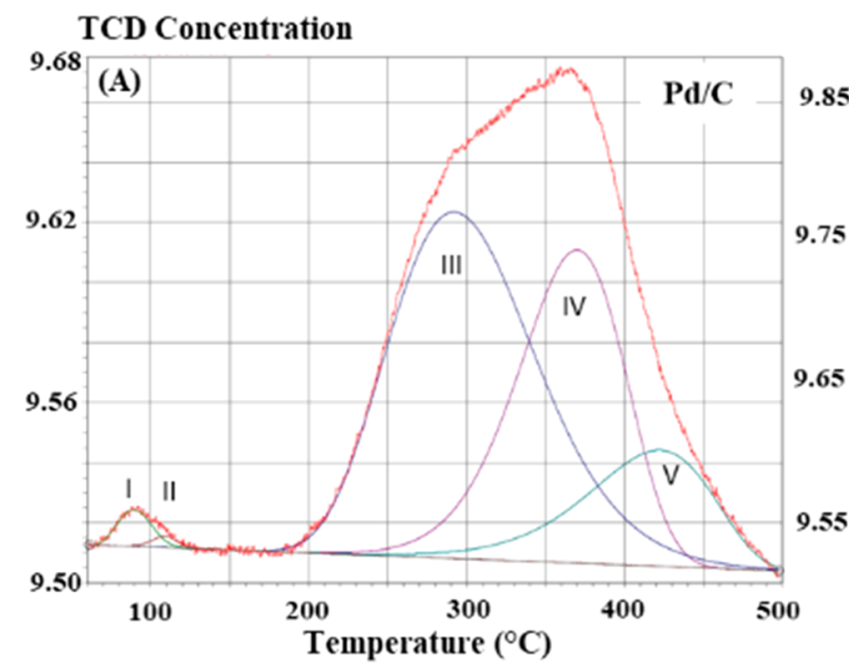

TCD Concentration

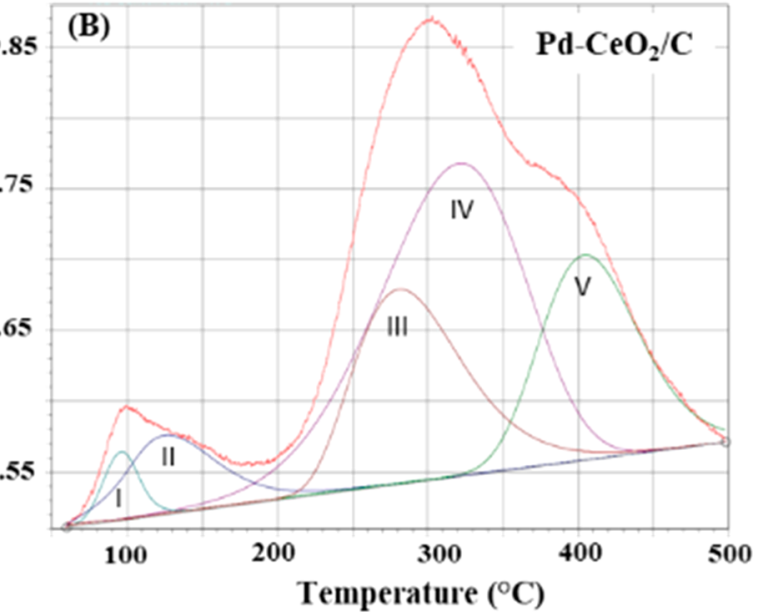

Figure 5. Deconvolution of $\mathrm{H}_{2}$-TPD spectra for (A) $\mathrm{Pd} / \mathrm{C}$ and (B) $\mathrm{Pd}-\mathrm{CeO}_{2} / \mathrm{C}$ catalysts. Temperature ramp $=10^{\circ} \mathrm{min}^{-1}$. 
Table 2. Comparison of $\mathrm{H}_{2}-\mathrm{TPD}$ data for $\mathrm{Pd} / \mathrm{C}$ and $\mathrm{Pd}-\mathrm{CeO}_{2} / \mathrm{C}$

\begin{tabular}{|c|c|c|c|c|c|c|c|c|}
\hline \multirow[b]{2}{*}{ peak } & \multicolumn{4}{|c|}{$10 \% \mathrm{Pd} / \mathrm{C}$} & \multicolumn{4}{|c|}{$10 \% \mathrm{Pd}-\mathrm{CeO}_{2} / \mathrm{C}$} \\
\hline & $t\left({ }^{\circ} \mathrm{C}\right)$ & $\mathrm{mmol}\left(\mathrm{H}_{2}\right) / \mathrm{g}_{\text {cat }}$ & ratio & $\mathrm{H} / \mathrm{Pd}^{a}$ & $t\left({ }^{\circ} \mathrm{C}\right)$ & $\mathrm{mmol}\left(\mathrm{H}_{2}\right) / \mathrm{g}_{\text {cat }}$ & ratio & $\mathrm{H} / \mathrm{Pd}$ \\
\hline I & 91.5 & 0.00706 & 0.016 & 0.015 & 95.8 & 0.00954 & 0.016 & 0.020 \\
\hline II & & & & & 121.7 & 0.04747 & 0.083 & 0.101 \\
\hline$\sum \mathrm{I}+\mathrm{II}$ & & 0.00706 & 0.016 & 0.015 & & 0.05701 & 0.099 & 0.121 \\
\hline III & 292.0 & 0.20307 & 0.470 & 0.432 & 275.9 & 0.06447 & 0.113 & 0.138 \\
\hline IV & 370.3 & 0.12546 & 0.290 & 0.267 & 313.8 & 0.30893 & 0.537 & 0.658 \\
\hline $\mathrm{V}$ & 411.5 & 0.09641 & 0.284 & 0.205 & 405.8 & 0.08673 & 0.151 & 0.185 \\
\hline$\sum \mathrm{III}+\mathrm{IV}+\mathrm{V}$ & & 0.42494 & 0.984 & 0.904 & & 0.46039 & 0.801 & 0.980 \\
\hline$\Sigma$ & & 0.42494 & 1.00 & 0.919 & & 0.57441 & 1.00 & 1.223 \\
\hline
\end{tabular}

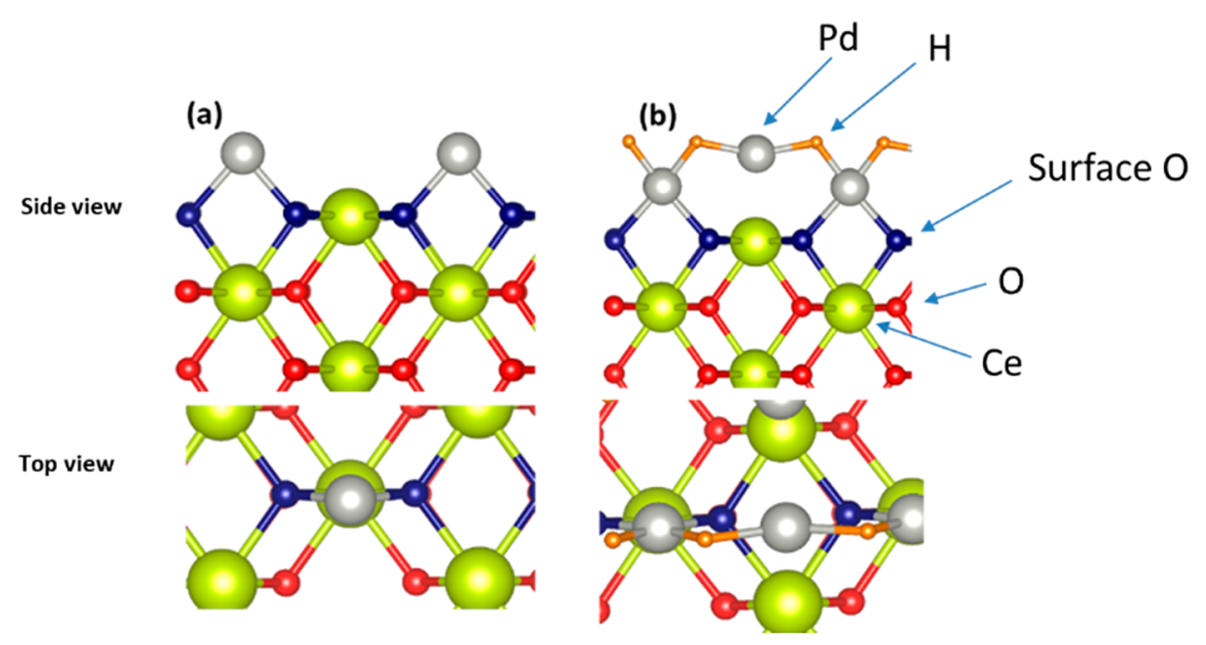

Figure 6. (a) Adsorption of $\mathrm{Pd}$ on bridge site between the $\mathrm{O}$ atoms of the $\mathrm{CeO}_{2}$ (110) (b) Adsorption of $\mathrm{H}$ in between the $\mathrm{Pd}$ atoms. Green, gray, and orange balls represents $\mathrm{Ce}, \mathrm{Pd}$, and $\mathrm{H}$ atoms, respectively. $\mathrm{O}$ atoms are shown in red and blue to distinguish the surface $\mathrm{O}$ atoms (blue) from other $\mathrm{O}$ atoms (red) in the slab.

$150{ }^{\circ} \mathrm{C}$ (Figure 5) can be attributed to $\beta$-phase decomposition. In this region, the amount of $\mathrm{H}$ atoms per $\mathrm{Pd}$ atom $(\mathrm{H} / \mathrm{Pd}$ ratio data in Table 2) for $\mathrm{Pd} / \mathrm{C}$ is 0.015 and is almost 1 order of magnitude lower than that for the $\mathrm{Pd} / \mathrm{C}-\mathrm{CeO}_{2}$. Comparison of $\mathrm{H}_{2}$-TPD data with the DFT calculations (see below) allow us to assume that the higher affinity of Pd$\mathrm{CeO}_{2} / \mathrm{C}$ to hydrogen dissolution might result in its lower affinity to hydrogen chemisorption. The assumption is in good agreement with earlier reported results showing that $\mathrm{H}$ binds less strongly to $\mathrm{Pd}$ hydride than to $\mathrm{Pd}^{45}$ The higher temperature peaks III, IV, and V can be assigned to strong adsorption of hydrogen, mostly to the spillover, transport, and storage of chemisorbed $\mathrm{H}$ atoms on the supporting $\mathrm{CeO}_{2}$ material. $^{46,47}$ The overall ratio of $\mathrm{H} / \mathrm{Pd}$ (Table 2) for $\mathrm{Pd} / \mathrm{C}$ catalyst is 0.92 , compared to 1.22 for the $\mathrm{Pd}-\mathrm{CeO}_{2} / \mathrm{C}$. The higher adsorption of $\mathrm{H}_{2}$ in $\mathrm{Pd}-\mathrm{CeO}_{2} / \mathrm{C}$ can hence be assigned to the well-known $\mathrm{H}_{2}$ spillover capacity of $\mathrm{CeO}_{2} \cdot{ }^{48-50} \mathrm{By}$ comparison, values of $\mathrm{H} / \mathrm{Pd}$ reported in literature for $\mathrm{Pd} / \mathrm{C}$ catalysts lie within a large range of $0.005-0.77 .^{51}$

3.2. DFT Calculations. The $\mathrm{CeO}_{2}-\mathrm{Pd}$ system was modeled by the deposition of $\mathrm{Pd}$ atoms on the top of the $\mathrm{CeO}_{2}$ (110) surface. We investigated different possible adsorption sites for the $\mathrm{Pd}$ binding on the $\mathrm{CeO}_{2}(110)$ surface and found that $\mathrm{Pd}$ prefers to be in the bridge position between the $\mathrm{O}$ atoms of the $\mathrm{CeO}_{2}$ (Figure 6a), which is consistent with previous reports. ${ }^{52,53}$ We calculated the $\mathrm{HBE}$ of $\mathrm{Pd}-\mathrm{CeO}_{2}$ as compared to $\mathrm{Pd}$. This has been described as one possible descriptor for the HOR and has been investigated for other systems using DFT calculations. ${ }^{54,55}$ We found that $\mathrm{H}$ prefers to adsorb in the bridge site between the Pd atoms, as shown in Figure $6 \mathrm{~b}$, and the $\mathrm{HBE}$ (relative to the gas phase $\mathrm{H}_{2}$ ) changes from $-0.80 \mathrm{eV}$ for $\mathrm{Pd}(111)$ to $-0.46 \mathrm{eV}$ for the $\mathrm{Pd}-\mathrm{CeO}_{2}$ surface (Tables 3 and S3). Since the HBE of the Pd metal is

Table 3. $\mathrm{H}$ Binding Energy on $\mathrm{Pd}-\mathrm{CeO}_{2}$ Substrate $^{a}$

\begin{tabular}{lccc}
\multicolumn{1}{c}{ structure } & $E_{\text {ad }}$ & $\begin{array}{c}\mathrm{HBE} \\
\left(1 / 2 \mathrm{H}_{2} \text { as ref }\right)\end{array}$ & $\begin{array}{c}\text { external potential }(U)=0 \mathrm{~V} \\
\left(1 / 2 \mathrm{H}_{2}\right)\end{array}$ \\
$\mathrm{Pd}(111)$ & -4.14 & -0.80 & -1.03 \\
$\mathrm{Pd}-\mathrm{CeO}_{2}$ & -3.80 & -0.46 & -0.67 \\
2 layer $\mathrm{Pd}$ on & -4.05 & -0.71 & -0.94 \\
$\mathrm{CeO}_{2}$ & & & -0.93 \\
3 layer $\mathrm{Pd}$ on & -4.03 & -0.70 & \\
$\mathrm{CeO}_{2}$ & & \\
${ }^{a}$ The $\mathrm{HBE}$ is in electronvolts per $\mathrm{H}$ atom.
\end{tabular}

located on the left side of the volcano curve of HOR activity, the HOR activity is expected to be enhanced by a slight shift of the HBE to higher (more positive) values. Therefore, the weaker $\mathrm{H}$ adsorption strength on $\mathrm{Pd}-\mathrm{CeO}_{2}$ is consistent with our experimental observations of higher HOR activity.

The variation of $\mathrm{HBE}$ with the number of Pd layers on $\mathrm{CeO}_{2}$ (110) surface was also investigated. Our calculations show that one monolayer (ML) of $\mathrm{Pd}$ on $\mathrm{CeO}_{2}$ is catalytically more active for HOR than with multiple layers of Pd (Table 3). The significant direct metal-substrate interaction between the first layer of $\mathrm{Pd}$ atoms and $\mathrm{O}$ atoms of $\mathrm{CeO}_{2}$ surface deactivates the 

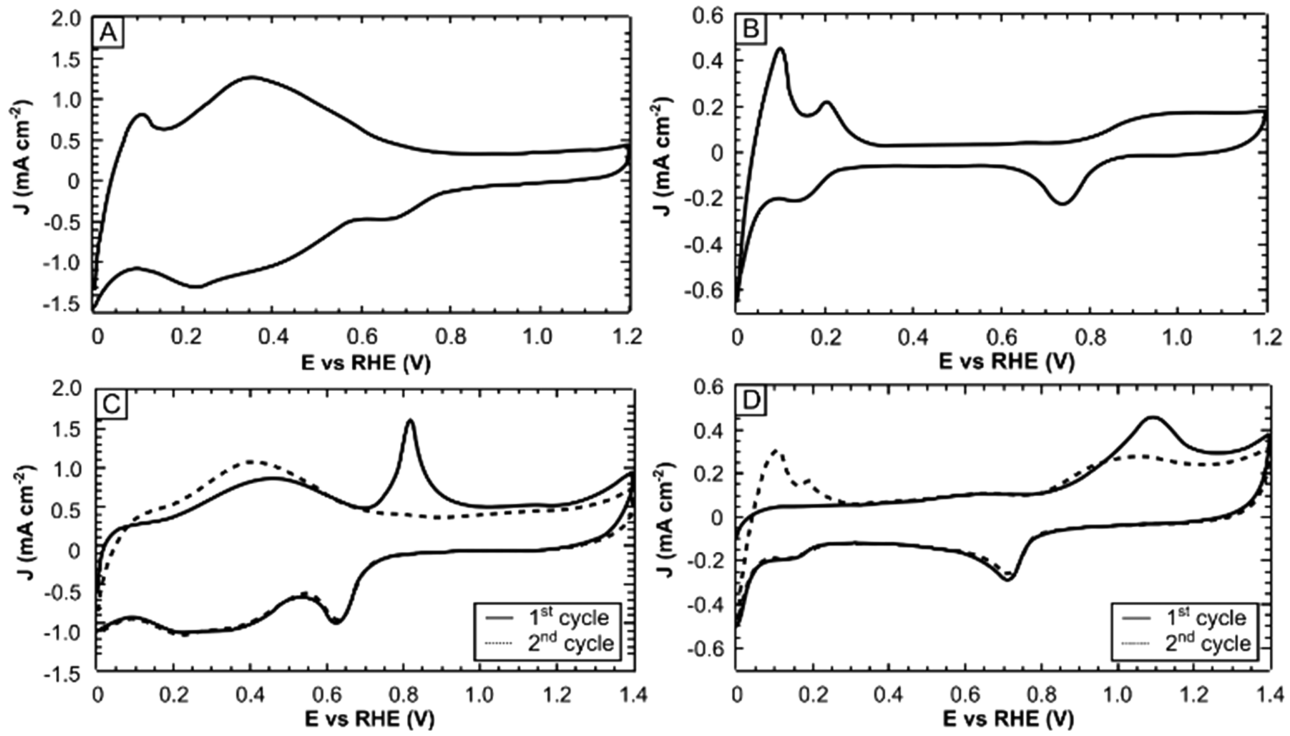

Figure 7. Cyclic voltammetry of $\mathrm{Pd}-\mathrm{CeO}_{2} / \mathrm{C}$ in static $\mathrm{N}_{2}$-saturated aqueous solutions of $(\mathrm{A}) \mathrm{KOH}(0.1 \mathrm{M})$ and $(\mathrm{B}) \mathrm{HClO}_{4}(0.2 \mathrm{M})\left(50 \mathrm{mV} \mathrm{s}{ }^{-1}\right)$. $\mathrm{CO}$ stripping voltammetry in aqueous solutions of $(\mathrm{C}) \mathrm{KOH}(2 \mathrm{M})$ and $(\mathrm{D})$ in $\mathrm{HClO}_{4}(0.2 \mathrm{M})\left(20 \mathrm{mV} \mathrm{s}^{-1}\right)$.
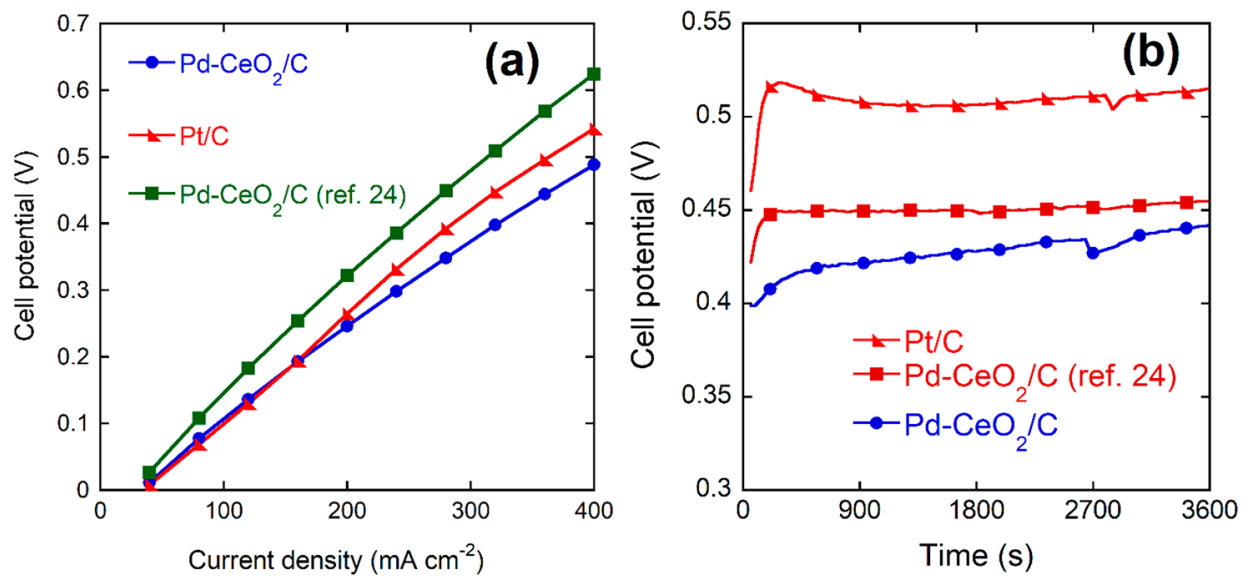

Figure 8. (a) Polarization curves of $\mathrm{H}_{2}$ pumping tests (anode loadings: $\mathrm{Pt} / \mathrm{C}=0.45 \mathrm{mg} \mathrm{cm}{ }^{-2}$ and $\mathrm{Pd}-\mathrm{CeO}_{2} / \mathrm{C}=0.2 \mathrm{mg} \mathrm{cm}{ }^{-2}$ ) and $(\mathrm{b})$ cell performance at a constant current density of $300 \mathrm{~mA} \mathrm{~cm}{ }^{-2}$ for $1 \mathrm{~h}\left(T_{\text {cell }}=60^{\circ} \mathrm{C}\right.$, anode $\mathrm{H}_{2}$ and cathode $\mathrm{N}_{2}$ flow rates both $0.1 \mathrm{~L}$ min ${ }^{-1}$, cathode electrode $\mathrm{Pt} / \mathrm{C}=0.45 \mathrm{mg} \mathrm{cm}^{-2}$ ).

H-bond strength, whereas the second and third layers of $\mathrm{Pd}$ lack this direct metal-substrate interaction. As a result, the system almost behaves like bulk Pd, which leads to stronger binding. Nevertheless, even for two and three layers, the HBE is slightly deactivated compared to $\operatorname{Pd}(111)$, suggesting that the HOR activity will be enhanced in this case as well. This also suggests that very small particles or single atoms of Pd will produce higher HOR activity. The XAS data demonstrates that the $\mathrm{Pd}$ in the $\mathrm{Pd}-\mathrm{CeO}_{2} / \mathrm{C}$ catalyst exists in such a structure. In addition, this structure results in enhanced activity for the HOR under alkaline conditions as demonstrated in the electrochemical studies that follow.

3.3. Electrochemical Characterization. The synthesis of $\mathrm{Pd}-\mathrm{CeO}_{2} / \mathrm{C}$ was repeated five times on a $0.5 \mathrm{~g}$ scale to confirm repeatability. Tafel analysis was undertaken for each sample (Figure S11). The average values of Tafel slope and exchange current densities are $70 \mathrm{mV} \mathrm{dec}^{-1}$ and $20 \mathrm{~A} \mathrm{~g}_{\mathrm{Pd}}{ }^{-1}$, respectively. Cyclic voltammetry $(\mathrm{CV})$ in $\mathrm{N}_{2}$ saturated aqueous $\mathrm{KOH}(0.1 \mathrm{M})$ shows $\mathrm{Pd}$ centered redox transitions that are broadened (usually well-defined under these conditions) with a much higher capacitive current density (Figure 7A).
Additionally, there is a large contribution from $\mathrm{CeO}_{2}$ centered transitions in the $\mathrm{H}_{\text {UPD }}$ zone in alkaline conditions, which are absent in acid media (Figure 7B). CO stripping voltammetry was undertaken in both alkaline (Figure $7 \mathrm{C}$ ) and acidic (Figure 7D) conditions. The charge associated with the $\mathrm{CO}$ stripping peak was used to determine a value for the electrochemically active surface area (ECSA) of $63 \mathrm{~m}^{2} \mathrm{~g}_{\mathrm{Pd}}{ }^{-1}$.

$\mathrm{H}_{2}$ pump electrochemical tests were used to evaluate and compare the $\mathrm{HOR}$ activity of $\mathrm{Pd}-\mathrm{CeO}_{2} / \mathrm{C}$ to reference catalysts in a simulated fuel cell environment. The catalyst was compared to commercial 40\% wt. Pt/C (Alfa Aesar) and the $\mathrm{Pd}-\mathrm{CeO}_{2}$ catalyst previously reported. ${ }^{24,25}$ The membrane electrode assemblies (MEAs) were formed by pressing together the anode and cathode to the commercial AEM within the cell hardware (no prior hot pressing). The MEAs were tested using polarization curves at $60{ }^{\circ} \mathrm{C}$ with humidified gases at both electrodes. The details of each catalyst studied and important data are listed in Table S2. The polarization curves (Figure $8 \mathrm{a}$ ) show that the activity of $\mathrm{Pd}-\mathrm{CeO}_{2} / \mathrm{C}$ (in a fuel cell relevant MEA) outperforms a $\mathrm{Pt} / \mathrm{C}$ anode even with half the metal loading $\left(0.2\right.$ vs $\left.0.4 \mathrm{mg}_{\mathrm{PGM}} \mathrm{cm}^{-2}\right)$. This is 
corroborated using constant current density $\left(300 \mathrm{~mA} \mathrm{~cm}{ }^{-2}\right)$ load tests with each catalyst (Figure 8b).

3.4. AEMFC Testing. We performed AEMFC testing to evaluate the $\mathrm{HOR}$ activity of the $\mathrm{Pd}-\mathrm{CeO}_{2} / \mathrm{C}$ catalyst under fuel cell conditions. A benzyltrimethylammonium radiation grafted LDPE (low density polyethylene) AEM was used (30 $\mu \mathrm{m}$ hydrated, IEC $\left.=2.54 \mathrm{mmol} \mathrm{g}^{-1}\right)$, as this class of membrane has excellent properties (conductivity, water back diffusion kinetics) and has been well proven in high-performance AEMFCs. ${ }^{34-37,56-58}$ Cell conditions and all materials were kept constant including the cathode electrode and AEM with the exception of the anode catalyst. Two anode electrodes with the same catalyst and metal loading were prepared with (a) $\mathrm{Pd}-\mathrm{CeO}_{2} / \mathrm{C}$ and (b) the previously reported $\mathrm{Pd}-\mathrm{CeO}_{2}$ catalyst $^{24}$ (the latter as a reference material). The Pd loading was kept constant $\left(0.25 \mathrm{mg}_{\mathrm{Pd}} \mathrm{cm}^{-2}\right)$. Significantly higher power densities were obtained (Figure 9) with the nano-

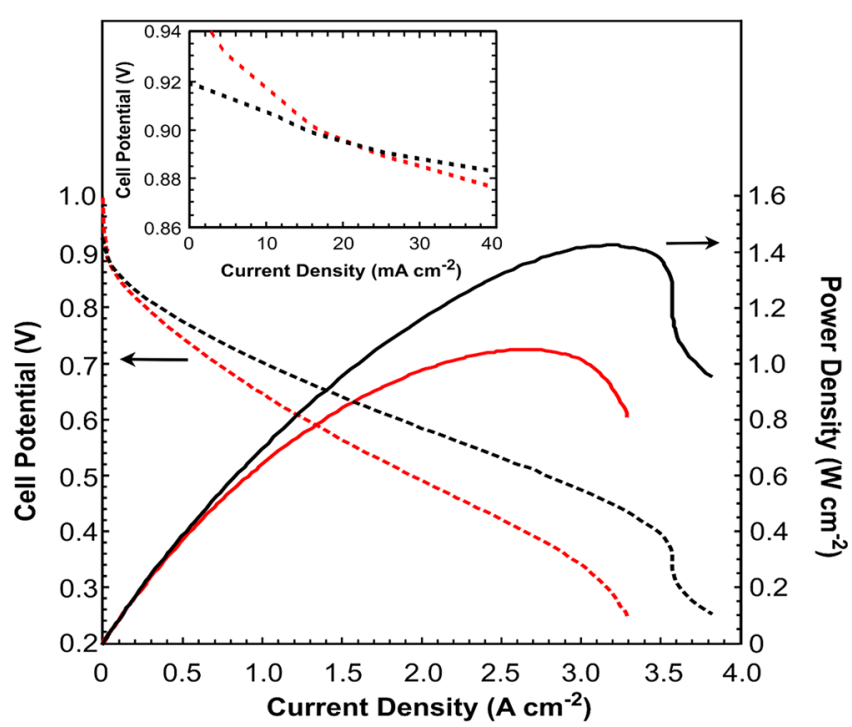

Figure 9. $\mathrm{H}_{2} / \mathrm{O}_{2}$ AEMFC performance data with $\mathrm{Pd}-\mathrm{CeO}_{2} / \mathrm{C}$ anode catalysts $\left(0.25 \mathrm{mg}_{\mathrm{Pd}} \mathrm{cm}^{-2}\right.$ loading), and a $40 \%$ wt. Pt/C cathode (0.4 $\mathrm{mg} \mathrm{cm}{ }^{-2} \mathrm{Pt}$ loading): The $\mathrm{Pd}-\mathrm{CeO}_{2} / \mathrm{C}$ described in this work (black curves) and a reference catalyst (red curves). ${ }^{24}$ Both electrodes contain $20 \%$ wt. of radiation-grafted ETFE-based anion-exchange ionomer (AEI) powder ionomer. $\mathrm{H}_{2}$ was provided to the anode at 1.0 $\mathrm{L} \mathrm{min}^{-1} \cdot \mathrm{O}_{2}$ was fed to the cathode at $2.0 \mathrm{~L} \mathrm{~min}{ }^{-1}$. The cell temperature was $80^{\circ} \mathrm{C}$ and anode/cathode dew-points were both 76 ${ }^{\circ} \mathrm{C}$ (no back-pressurization).

structured $\mathrm{Pd}-\mathrm{CeO}_{2} / \mathrm{C}$ catalyst. Within the initial activation (electrokinetic) region (see Figure 9 insert) this catalyst has higher activity at all potentials below $0.9 \mathrm{~V}$. Interestingly, the ohmic and mass transport losses are also significantly reduced. This must all be attributable to the new improved $\mathrm{Pd}-\mathrm{CeO}_{2}$ interface obtained through the new synthesis procedure as all other aspects (materials, loadings, and cell test conditions) were fixed. The internal ohmic resistance was monitored during testing and shows also an improved conductivity of the $\mathrm{Pd}-\mathrm{CeO}_{2} / \mathrm{C}$ MEA (see Figure S12). Hence, the new catalyst also enables an enhanced catalyst-ionomer dispersion within the electrode layer leading to higher ionic conductivity for passage of the $\mathrm{OH}^{-}$anions. Under the same gas feeding conditions, the enhanced activity (current densities above 3.5 $\mathrm{A} \mathrm{cm}^{-2}$ ) results in the appearance of larger mass transfer losses, clearly seen in the curve for $\mathrm{Pd}-\mathrm{CeO}_{2} / \mathrm{C}$ that we believe is due to anode flooding phenomena.

\section{CONCLUSIONS}

This study demonstrates that Pt-free hydrogen oxidation reaction electrocatalysts can be developed for high power density anion-exchange membrane fuel cells. A key aspect of this challenge is overcoming the poor activity of HOR catalysts in alkaline media. In doing this, we must also seek to gain clearer understanding of the nature of the activity descriptors for HOR catalysts in alkali in which there remains some debate. Having shown that certain $\mathrm{Pd}-\mathrm{CeO}_{2}$ interactions enhance the HOR activity of $\mathrm{Pd}$ in alkali, we have endeavored to describe the origin of this activity enhancement as well as engineer the catalyst structure and synthesis procedure to maximize the performance of this new class of fuel cell electrocatalyst. The preparation method, involving an organometallic cerium-based precursor, allowed us to obtain an optimized $\mathrm{Pd}-\mathrm{CeO}_{2}$ contact on the nanoscale. XAS investigations confirm this structure and DFT calculations have shown how $\mathrm{Pd}$ in this structure has a weakened interaction with adsorbed $\mathrm{H}$. At the same time, the $\mathrm{H}_{2}$ spillover capacity of $\mathrm{CeO}_{2}$ in the catalyst facilitates the adsorption of more $\mathrm{H}_{2}$ per Pd. The enhanced HOR activity of this $\mathrm{Pd}-\mathrm{CeO}_{2} / \mathrm{C}$ catalyst allowed us to obtain $1.4 \mathrm{~W} \mathrm{~cm}^{-2}$ of peak power density in $\mathrm{H}_{2} / \mathrm{O}_{2}$ AEMFC testing (a new record for a non-Pt anode catalyst).

\section{ASSOCIATED CONTENT}

\section{Supporting Information}

The Supporting Information is available free of charge on the ACS Publications website at DOI: 10.1021/acsaem.9b00657.

Detailed material characterization; TGA, HAADFSTEM, EDS mapping, electron tomography, and $\mathrm{H}_{2}$ TPD curves; and electrochemical data Tafel curves, $\mathrm{H}_{2}$-pump data, and fuel cell ohmic resistance measurements (PDF)

\section{AUTHOR INFORMATION}

\section{Corresponding Authors}

*E-mail: hamish.miller@iccom.cnr.it.

*E-mail: francesco.vizza@iccom.cnr.it.

*E-mail: pfornasiero@units.it.

*E-mail: dario@technion.ac.il.

ORCID ${ }^{\circ}$

Paolo Fornasiero: 0000-0003-1082-9157

Claudio Evangelisti: 0000-0002-8855-2592

Chethana B. Krishnamurthy: 0000-0002-7615-5688

Dario R. Dekel: 0000-0002-8610-0808

Hamish A. Miller: 0000-0003-1668-6476

\section{Notes}

The authors declare no competing financial interest.

\section{ACKNOWLEDGMENTS}

This research used beamline 8-ID (ISS) of the National Synchrotron Light Source II, a U.S. Department of Energy (DOE) Office of Science User Facility operated for the DOE Office of Science by Brookhaven National Laboratory under Contract No. DE-SC0012704. This work was partially funded by the Nancy \& Stephan Grand Technion Energy Program (GTEP); by the European Union's Horizon 2020 research and 
innovation program [Grant 721065]; by the Ministry of Science, Technology \& Space of Israel through the M.EraNET Transnational Call 2015, NEXTGAME project [Grant 312940], through Grant 3-12948; by the Israel Science Foundation (ISF) [Grant 1481/17]; by the Israeli Committee of High Education and the Israeli Prime Minister office via the INREP project; by the Russell Berrie Nanotechnology Institute, Technion; and by the Ministry of National Infrastructure, Energy and Water Resources of Israel [Grant 3-13671]. This research was also partially carried out within the framework of the UConn-Technion Energy Collaboration initiative, supported by the Satell Family Foundation, the Maurice G. Gamze Endowed Fund (at the American Technion Society), Larry Pitt and Phillis Meloff, The Eileen and Jerry Lieberman UConn/Israel Global Partnership Fund and the Grand Technion Energy Program (GTEP). The authors would also like to thank 4D Laboratories at the Simon Fraser University, Burnaby, Canada, for access to the TEM instrument. The authors also thank Ente Cassa di Risparmio di Firenze for funding (project EnergyLab) and PRIN 2018 Project funded by Italian Ministry MUIR Italy (Grant 2017YH9MRK). The radiation-grafted ionomer powder and AEM development and AEMFC testing was funded by the UK's Engineering Physical Sciences Research Council (EPSRC Grant EP/M014371/1). The collaboration between the University of Surrey and ICCOM (CNR) teams was facilitated by funding awarded by the Royal Society's international exchange scheme (Grant IES $\backslash \mathrm{R} 3 \backslash 170134$ ).

\section{REFERENCES}

(1) Elbert, K.; Hu, J.; Ma, Z.; Zhang, Y.; Chen, G. Y.; An, W.; Liu, P.; Isaacs, H. S.; Adzic, R. R.; Wang, J. X. Elucidating Hydrogen Oxidation/Evolution Kinetics in Base and Acid by Enhanced Activities at the Optimized Pt Shell Thickness on the $\mathrm{Ru}$ Core. ACS Catal. 2015, 5 (11), 6764-6772.

(2) Ramaswamy, N.; Ghoshal, S.; Bates, M. K.; Jia, Q. Y.; Li, J. K.; Mukerjee, S. Hydrogen oxidation reaction in alkaline media: Relationship between electrocatalysis and electrochemical doublelayer structure. Nano Energy 2017, 41, 765-771.

(3) Davydova, E. S.; Mukerjee, S.; Jaouen, F.; Dekel, D. R. Electrocatalysts for Hydrogen Oxidation Reaction in Alkaline Electrolytes - A Review. ACS Catal. 2018, 8 (7), 6665-6690.

(4) Dekel, D. R.; Amar, M.; Willdorf, S.; Kosa, M.; Dhara, S.; Diesendruck, C. E. Effect of Water on the Stability of Quaternary Ammonium Groups for Anion Exchange Membrane Fuel Cell Applications. Chem. Mater. 2017, 29 (10), 4425-4431.

(5) Amel, A.; Smedley, S. B.; Dekel, D. R.; Hickner, M. A.; Ein-Eli, Y. Characterization and Chemical Stability of Anion Exchange Membranes Cross-Linked with Polar Electron-Donating Linkers. J. Electrochem. Soc. 2015, 162 (9), F1047-F1055.

(6) Amel, A.; Gavish, N.; Zhu, L.; Dekel, D. R.; Hickner, M. A.; EinEli, Y. Bicarbonate and chloride anion transport in anion exchange membranes. J. Membr. Sci. 2016, 514, 125-134.

(7) Pusara, S.; Srebnik, S.; Dekel, D. R. Molecular Simulation of Quaternary Ammonium Solutions at Low Hydration Levels. J. Phys. Chem. C 2018, 122 (21), 11204-11213.

(8) Dekel, D. R.; Willdorf, S.; Ash, U.; Amar, M.; Pusara, S.; Dhara, S.; Srebnik, S.; Diesendruck, C. E. The critical relation between chemical stability of cations and water in anion exchange membrane fuel cells environment. J. Power Sources 2018, 375, 351-360.

(9) Gottesfeld, S.; Dekel, D. R.; Page, M.; Bae, C.; Yan, Y. S.; Zelenay, P.; Kim, Y. S. Anion exchange membrane fuel cells: Current status and remaining challenges. J. Power Sources 2018, 375, 170-184.

(10) Dekel, D. R. Review of cell performance in anion exchange membrane fuel cells. J. Power Sources 2018, 375, 158-169.
(11) Miller, H. A.; Vizza, V. Electrocatalysts and Mechanisms of Hydrogen Oxidation in Alkaline Media for Anion Exchange Membrane Fuel Cells. Anion Exchange Membrane Fuel Cells: Principles, Materials and Systems. Lecture Notes in Energy 2018, 63, 79-103.

(12) Durst, J.; Siebel, A.; Simon, C.; Hasche, F.; Herranz, J.; Gasteiger, H. A. New insights into the electrochemical hydrogen oxidation and evolution reaction mechanism. Energy Environ. Sci. 2014, 7 (7), 2255-2260.

(13) Li, J.; Ghoshal, S.; Bates, M. K.; Miller, T. E.; Davies, V.; Stavitski, E.; Attenkofer, K.; Mukerjee, S.; Ma, Z. F.; Jia, Q. Experimental proof of the bifunctional mechanism for the hydrogen oxidation in alkaline media. Angew. Chem., Int. Ed. 2017, 56 (49), 15594-155598.

(14) Schwämmlein, J. N.; El-Sayed, H. L.; Stühmeier, B. M.; Wagenbauer, K. F.; Dietz, H.; Gasteiger, H. A. Origin of Superior Activity of Ru@Pt Core-Shell Nanoparticles towards Hydrogen Oxidation in Alkaline Media. ECS Trans. 2016, 75, 971-982.

(15) Lu, S. Q.; Zhuang, Z. B. Investigating the Influences of the Adsorbed Species on Catalytic Activity for Hydrogen Oxidation Reaction in Alkaline Electrolyte. J. Am. Chem. Soc. 2017, 139 (14), $5156-5163$

(16) Cong, Y. Y.; Yi, B. L.; Song, Y. J. Hydrogen oxidation reaction in alkaline media: From mechanism to recent electrocatalysts. Nano Energy 2018, 44, 288-303.

(17) Wang, T. Y.; Xie, H.; Chen, M. J.; D’Aloia, A.; Cho, J.; Wu, G.; Li, Q. Precious metal-free approach to hydrogen electrocatalysis for energy conversion: From mechanism understanding to catalyst design. Nano Energy 2017, 42, 69-89.

(18) Yang, F. L.; Fu, L. H.; Cheng, G. Z.; Chen, S. L.; Luo, W. Iroriented nanocrystalline assemblies with high activity for hydrogen oxidation/evolution reactions in an alkaline electrolyte. J. Mater. Chem. A 2017, 5 (44), 22959-22963.

(19) Sheng, W. C.; Myint, M.; Chen, J. G. G.; Yan, Y. S. Correlating the hydrogen evolution reaction activity in alkaline electrolytes with the hydrogen binding energy on monometallic surfaces. Energy Environ. Sci. 2013, 6 (5), 1509-1512.

(20) Henning, S.; Herranz, J.; Gasteiger, H. A. Bulk-Palladium and Palladium-on-Gold Electrocatalysts for the Oxidation of Hydrogen in Alkaline Electrolyte. J. Electrochem. Soc. 2015, 162 (1), F178-F189.

(21) Wang, Y.; Wang, G. W.; Li, G. W.; Huang, B.; Pan, J.; Liu, Q.; Han, J. J.; Xiao, L.; Lu, J. T.; Zhuang, L. Pt-Ru catalyzed hydrogen oxidation in alkaline media: oxophilic effect or electronic effect? Energy Environ. Sci. 2015, 8 (1), 177-181.

(22) Li, Q.; Peng, H.; Wang, Y.; Xiao, L.; Lu, J.; Zhuang, L. The Comparability of $\mathrm{Pt}$ to $\mathrm{Pt}-\mathrm{Ru}$ in Catalyzing the Hydrogen Oxidation Reaction for Alkaline Polymer Electrolyte Fuel Cells Operated at 80 ${ }^{\circ} \mathrm{C}$. Angew. Chem., Int. Ed. 2019, 58 (5), 1442-1446.

(23) Strmcnik, D.; Uchimura, M.; Wang, C.; Subbaraman, R.; Danilovic, N.; van der Vliet, D.; Paulikas, A. P.; Stamenkovic, V. R.; Markovic, N. M. Improving the hydrogen oxidation reaction rate by promotion of hydroxyl adsorption. Nat. Chem. 2013, 5 (4), 300-306.

(24) Miller, H. A.; Lavacchi, A.; Vizza, F.; Marelli, M.; Di Benedetto, F.; D'Acapito, F.; Paska, Y.; Page, M.; Dekel, D. R. A Pd/C-CeO2 Anode Catalyst for High-Performance Platinum-Free Anion Exchange Membrane Fuel Cells. Angew. Chem. Int. Edit 2016, 55 (20), 60046007.

(25) Miller, H. A.; Vizza, F.; Marelli, M.; Zadick, A.; Dubau, L.; Chatenet, M.; Geiger, S.; Cherevko, S.; Doan, H.; Pavlicek, R. K.; Mukerjee, S.; Dekel, D. R. Highly active nanostructured palladiumceria electrocatalysts for the hydrogen oxidation reaction in alkaline medium. Nano Energy 2017, 33, 293-305.

(26) Omasta, T. J. P.; Miller, H. A.; Vizza, F.; Wang, L.; Varcoe, J. R.; Dekel, D. R.; Mustain, W. E.; et al. Beyond $1.0 \mathrm{~W} \mathrm{~cm}-2$ Performance Without Platinum - The Beginning of a New Era in Anion Exchange Membrane Fuel Cells. J. Electrochem. Soc. 2018, 165 (15), J3039-J3044.

(27) Egorova, K. S.; Ananikov, V. P. Which Metals are Green for Catalysis? Comparison of the Toxicities of $\mathrm{Ni}, \mathrm{Cu}, \mathrm{Fe}, \mathrm{Pd}, \mathrm{Pt}, \mathrm{Rh}$, and Au Salts. Angew. Chem., Int. Ed. 2016, 55 (40), 12150-12162. 
(28) Yu, H.; Davydova, E. S.; Ash, U.; Miller, H. A.; Bonville, L.; Dekel, D. R.; Maric, R. Palladium-ceria nanocatalyst for hydrogen oxidation in alkaline media: Optimization of the $\mathrm{Pd}-\mathrm{CeO}_{2}$ interface. Nano Energy 2019, 57, 820-826.

(29) Cargnello, M.; Wieder, N. L.; Montini, T.; Gorte, R. J.; Fornasiero, P. Synthesis of Dispersible Pd@CeO2 Core-Shell Nanostructures by Self-Assembly. J. Am. Chem. Soc. 2010, 132 (4), $1402-1409$.

(30) Newville, M. IFEFFIT: interactive XAFS analysis and FEFF fitting. J. Synchrotron Radiat. 2001, 8, 322-324.

(31) Ravel, B.; Gallagher, K. Atomic structure and the magnetic properties of Zr-doped Sm2Co17. Phys. Scr. 2005, T115, 606-608.

(32) Newville, M.; Livins, P.; Yacoby, Y.; Rehr, J. J.; Stern, E. A. Near-Edge X-Ray-Absorption Fine-Structure of $\mathrm{Pb}-\mathrm{a}$ Comparison of Theory and Experiment. Phys. Rev. B: Condens. Matter Mater. Phys. 1993, 47 (21), 14126-14131.

(33) Ankudinov, A. L.; Ravel, B.; Rehr, J. J.; Conradson, S. D. Realspace multiple-scattering calculation and interpretation of $\mathrm{x}$-rayabsorption near-edge structure. Phys. Rev. B: Condens. Matter Mater. Phys. 1998, 58 (12), 7565-7576.

(34) Wang, L.; Magliocca, E.; Cunningham, E. L.; Mustain, W. E.; Poynton, S. D.; Escudero-Cid, R.; Nasef, M. M.; Ponce-Gonzalez, J.; Bance-Souahli, R.; Slade, R. C. T.; Whelligan, D. K.; Varcoe, J. R. An optimized synthesis of high performance radiation-grafted anionexchange membranes. Green Chem. 2017, 19 (3), 831-843.

(35) Wang, L. Q.; Brink, J. J.; Liu, Y.; Herring, A. M.; PonceGonzalez, J.; Whelligan, D. K.; Varcoe, J. R. Non-fluorinated preirradiation-grafted (peroxidated) LDPE-based anion-exchange membranes with high performance and stability. Energy Environ. Sci. 2017, 10 (10), 2154-2167.

(36) Lu, Y. X.; Wang, L. Q.; Preuss, K.; Qiao, M.; Titirici, M. M.; Varcoe, J.; Cai, Q. Halloysite-derived nitrogen doped carbon electrocatalysts for anion exchange membrane fuel cells. J. Power Sources 2017, 372, 82-90.

(37) Wang, L. Q.; Bellini, M.; Miller, H. A.; Varcoe, J. R. A high conductivity ultrathin anion-exchange membrane with $500+\mathrm{h}$ alkali stability for use in alkaline membrane fuel cells that can achieve $2 \mathrm{~W}$ $\mathrm{cm}(-2)$ at 80 degrees C. J. Mater. Chem. A 2018, 6 (31), 1540415412 .

(38) Blum, V.; Gehrke, R.; Hanke, F.; Havu, P.; Havu, V.; Ren, X. G.; Reuter, K.; Scheffler, M. Ab initio molecular simulations with numeric atom-centered orbitals. Comput. Phys. Commun. 2009, 180 (11), 2175-2196.

(39) Vanlenthe, E.; Baerends, E. J.; Snijders, J. G. Relativistic TotalEnergy Using Regular Approximations. J. Chem. Phys. 1994, 101 (11), 9783-9792.

(40) Perdew, J. P.; Burke, K.; Ernzerhof, M. Generalized gradient approximation made simple. Phys. Rev. Lett. 1996, 77 (18), 38653868.

(41) Skulason, E.; Tripkovic, V.; Bjorketun, M. E.; Gudmundsdottir, S.; Karlberg, G.; Rossmeisl, J.; Bligaard, T.; Jonsson, H.; Norskov, J. K. Modeling the Electrochemical Hydrogen Oxidation and Evolution Reactions on the Basis of Density Functional Theory Calculations. J. Phys. Chem. C 2010, 114 (42), 18182-18197.

(42) Johansson, M.; Skulason, E.; Nielsen, G.; Murphy, S.; Nielsen, R. M.; Chorkendorff, I. Hydrogen adsorption on palladium and palladium hydride at 1 bar. Surf. Sci. 2010, 604 (7-8), 718-729.

(43) Amorim, C.; Keane, M. A. Palladium supported on structured and nonstructured carbon: A consideration of Pd particle size and the nature of reactive hydrogen. J. Colloid Interface Sci. 2008, 322 (1), 196-208.

(44) Redjel, A.; Boudjahem, A.-G.; Bettahar, M. Effect of palladium precursor and preparation method on the catalytic performance of $\mathrm{Pd} / \mathrm{SiO} 2$ catalysts for benzene hydrogenation. Particulate Science and Technology 2018, 36, 710-715.

(45) Konda, S. K.; Chen, A. C. Palladium based nanomaterials for enhanced hydrogen spillover and storage. Mater. Today 2016, 19 (2), 100-108.
(46) Vayssilov, G. N.; Lykhach, Y.; Migani, A.; Staudt, T.; Petrova, G. P.; Tsud, N.; Skala, T.; Bruix, A.; Illas, F.; Prince, K. C.; Matolin, V.; Neyman, K. M.; Libuda, J. Support nanostructure boosts oxygen transfer to catalytically active platinum nanoparticles. Nat. Mater. 2011, 10 (4), 310-315.

(47) Zhang, H. L.; Wang, J. L.; Zhang, Y. H.; Jiao, Y.; Ren, C. J.; Gong, M. C.; Chen, Y. Q. A study on H-2-TPR of Pt/ $\mathrm{Ce} 0.27 \mathrm{Zr} 0.73 \mathrm{O} 2$ and $\mathrm{Pt} / \mathrm{Ce} 0.27 \mathrm{Zr} 0.70 \mathrm{La} 0.03 \mathrm{Ox}$ for soot oxidation. Appl. Surf. Sci. 2016, 377, 48-55.

(48) Dutta, G.; Waghmare, U. V.; Baidya, T.; Hegde, M. S. Hydrogen spillover on $\mathrm{CeO} 2 / \mathrm{Pt}$ : Enhanced storage of active hydrogen. Chem. Mater. 2007, 19 (26), 6430-6436.

(49) Yan, Z.; Tomer, A.; Perrussel, G.; Ousmane, M.; Katryniok, B.; Dumeignil, F.; Ponchel, A.; Liebens, A.; Pera-Titus, M. A Pd/CeO2 "H-2 Pump" for the Direct Amination of Alcohols. ChemCatChem 2016, 8 (21), 3347-3352.

(50) Loglio, F.; Innocenti, M.; D’Acapito, F.; Felici, R.; Pezzatini, G.; Salvietti, E.; Foresti, M. L. Cadmium selenide electrodeposited by ECALE: electrochemical characterization and preliminary results by EXAFS. J. Electroanal. Chem. 2005, 575 (1), 161-167.

(51) Krishnankutty, N.; Vannice, M. A. The Effect of Pretreatment on Pd/C Catalysts 0.1. Adsorption and Absorption Properties. $J$. Catal. 1995, 155 (2), 312-326.

(52) Song, W. Y.; Su, Y. Q.; Hensen, E. J. M. A DFT Study of CO Oxidation at the Pd-CeO2(110) Interface. J. Phys. Chem. C 2015, 119 (49), 27505-27511.

(53) Li, W. Q.; Goverapet Srinivasan, S.; Salahub, D. R.; Heine, T. $\mathrm{Ni}$ on the $\mathrm{CeO} 2(110)$ and (100) surfaces: adsorption vs. substitution effects on the electronic and geometric structures and oxygen vacancies. Phys. Chem. Chem. Phys. 2016, 18 (16), 11139-11149.

(54) Skulason, E.; Tripkovic, V.; Bjorketun, M. E.; Gudmundsdottir, S.; Karlberg, G.; Rossmeisl, J.; Bligaard, T.; Jonsson, H.; Norskov, J. K. Modeling the Electrochemical Hydrogen Oxidation and Evolution Reactions on the Basis of Density Functional Theory Calculations (vol 114, pg 18182, 2010). J. Phys. Chem. C 2010, 114 (50), 2237422374.

(55) Zheng, J.; Nash, J.; Xu, B.; Yan, Y. Perspective-Towards Establishing Apparent Hydrogen Binding Energy as the Descriptor for Hydrogen Oxidation/Evolution Reactions. J. Electrochem. Soc. 2018, 165 (2), H27-H29.

(56) Ponce-Gonzalez, J.; Ouachan, I.; Varcoe, J. R.; Whelligan, D. K. Radiation-induced grafting of a butyl-spacer styrenic monomer onto ETFE: the synthesis of the most alkali stable radiation-grafted anionexchange membrane to date. J. Mater. Chem. A 2018, 6 (3), 823-827.

(57) Omasta, T. J.; Wang, L.; Peng, X.; Lewis, C. A.; Varcoe, J. R.; Mustain, W. E. Importance of balancing membrane and electrode water in anion exchange membrane fuel cells. J. Power Sources 2018 , $375,205-213$.

(58) Wang, L. Q.; Brink, J. J.; Varcoe, J. R. The first anion-exchange membrane fuel cell to exceed $1 \mathrm{~W} \mathrm{~cm}(-2)$ at 70 degrees $\mathrm{C}$ with a non-Pt-group (O-2) cathode. Chem. Commun. 2017, 53 (86), 1177111773. 